\title{
NEEDS ANALYSIS IN DESIGNING ENGLISH FOR YOUNG LEARNERS' MATERIAL AT RUBIK SOCIAL SCHOOL
}

\author{
Euis Kurniasih \\ Universitas Indraprasta PGRI \\ Jakarta, Indonesia \\ Euis99@gmail.com
}

\begin{abstract}
Many social institutions concerning on education field open English class for children by recruiting volunteer teachers. However, this voluntary English teaching activity makes the materials provided are not well structured so that the preparation of teaching materials is needed based on the needs of the learners involved. This research aims to identify the English learning needs in Rubik Social School. The method applied are observation, questionnaires and interview. The subject of research are the students and voluntary teachers. The results of the study include the target needs and learning needs. The target of English learning needs at the Rubik Social School is to support English subjects taught in formal schools and become the basis of skills for further education. The learning materials needed are simple vocabularies and expressions which topics are close to children such as parts of body, colors, family, fruits and vegetables and others. English learning is held in face-to-face meeting and taught by voluntary non-native speaker teachers every week. The results of this study should be continued as material for the producing of syllabus and teaching materials.
\end{abstract}

Keyword: needs analysis, English for young learners, Rubik social school

\section{INTRODUCTION}

The position of English as a global language makes many people have a high awareness of learning and teaching English. Without the ability to speak English, Indonesian people will have difficulties competing with the global community (Alwasilah, 1997). In fact, many parents feel prestigious if their children can speak English even though it is only a few simple words (Damayanti, 2008).

Through formal education at schools, English is a compulsory subject that is taught from junior high school to university level, while early childhood and elementary school levels are not mandatory. However, there are many schools, especially international schools and prestigious national schools that teach English lessons as a superior program and become an attraction for parents to send their children to these schools.

In addition to formal education, non-formal education such as course institutions through various publications of posters, flyers, or social media offers many English language learning programs with an offer so that children who take part in programs at these institutions have good English skills. In fact, apart from profit- 
oriented course institutions, there are also many teaching programs conducted by nonprofit social institutions. They usually recruit teaching volunteers and the students usually come from underprivileged groups.

One of the non-profit institutions that carry out English language teaching activities is the Rubik's Social School. Since its establishment in 2010. This Rubik's Social School is under the management of the Gemma Insani Foundation. Rubik's Social School opens social school programs in three places, namely Rubik 1 located in Kampung Sawah Kedung Waringin, Bojong Gede, Rubik 2 located in Kampung Lio Kedung Waringin, Bojong Gede and Rubik 3 located in Kampung Kandang Duren Mekar, Bojong Sari. With a mission to build a quality of young generation, the social school program is held every Sunday from two until five in the afternoon. Rubik's social school students are elementary school children. The number of students in each school is different, there are 25 students in Rubik 1, 50 students in Rubik 2 and 180 students in Rubik 3. One of the lessons given is English.

For the teaching program, Rubik's Social School recruits teaching volunteers. According to the Rubik's coordinator, the number of Rubik's volunteers currently consists of 10 people. Volunteer of English teachers come from students from various public and private universities in Jakarta. However, the presence of volunteers is not permanent, so they are always changing in an uncertain period of time.

In the implementation of learning, all students who come from different grade levels are united in the same class. A huge class with no age segmentation provides for a less favorable and effective learning environment. Students in larger classrooms are more dominant, but students in smaller classes simply follow and do not grasp enough information based on their grasping ability.

The presence of unpredictable volunteers make the English instruction program appears less viable between new volunteers and the previous volunteer. Furthermore, the English subject matter delivered to the pupils by the volunteers lacked a clear reference and goal. Without a specific aim for improving children's language skills, the new coordinator just recruits teaching volunteers and frees teachers to give materials according to their wishes.

As stated by Astika (1999) that needs analysis can bridge the current academic needs of students and the potential skills they must master later. In addition, by analyzing student needs, we will more easily adapt and develop teaching 
materials according to student needs so that learning objectives are more easily achieved (Lestari, 2014). This study aims to identify the needs of learning English in the Rubik's Social School.

Learning English for both general and specific purposes for children and adults requires an analysis of the learner's needs. In conducting a needs analysis there are two types of needs identified, namely target needs and learning needs (Hutchinson and Waters: 1987). Target needs consist of needs (necessities), deficiencies (lacks) and wants (wants). Needs refer to what students want to know when learning English. Weaknesses refer to what students already know before enrolling in various classes to learn English. Students' desires in studying English are referred to as desire.

Teachers must know and comprehend the qualities of their pupils since they have an impact on many elements of teaching, including teaching methods, teaching materials, lesson planning, and strategies to establish closeness and togetherness with them (Juhana, 2014). Harmer (2001) lists the following qualities of children: They respond to meaning even if they do not understand it word for word; they often learn indirectly or receive various kinds of information from all kinds of things around them; their understanding is not only from explanations but also from what they see, hear, touch, or can touch or interact with; they generally show enthusiasm for learning and have a curiosity about the world around them; they generally show enthusiasm for learning and have a curiosity about the world around them. They need personal attention and support from the teacher, they enjoy telling themselves stories and respond well to learning about themselves and their lives in class, and they have limited focus strength and are easily bored.

The instructor can establish a helpful classroom environment based on the characteristics of children who still have restrictions on anything abstract, their degree of awareness as a language learner is still low, and their range of concentration is still poor. Harmer (2001) recommends many approaches, the first of which is to make the classroom colorful and light, with windows so the children may see out. The space is intended to be large enough to accommodate a variety of activities. Even if it is possible to relocate youngsters to various classrooms for group activities. Create activities such as puzzles, making things, painting, playing, doing physical exercises, or singing for children who enjoy finding things and imagining. Ashemi and Azhihinezhad (2011) offer some practical 
tips for teachers in English classes for children, including using simple English in class, speaking clearly and briefly, using games, having a sense of humor, listening to music and watching cartoons in English, using cassettes and CDs for pronunciation examples, observing a good language class, using body language if needed, using real objects, adjusting the sitting position of children, calling them by their first names, and dress appropriately.

Based on the situation at the Rubik's Social School, many programs are needed to improve the quality of learning, one of which is composing syllabus and teaching materials so that the material provided by teaching volunteers to students is more focused. However, before making the syllabus and teaching materials, it is necessary to analyze the needs (needs analysis) so that the contents of the syllabus and teaching materials are more targeted according to the needs of the learner.

\section{METHOD}

This study takes a qualitative approach to learning English, focusing on the students' backgrounds, the motives for learning English, the materials that should be taught, and how the information should be delivered based on the students' backgrounds. According to Cresswell (1994), qualitative research is the process of gaining a holistic understanding of social and human problems by describing the informant's point of view in detail and conducting it in a natural setting.

The subjects in this study were volunteer teachers and students of the Rubik's Social School. There are 61 elementary school students at Rubik's Social School, with 14 third graders, 17 fourth graders, 21 fifth graders, and 9 sixth graders. There are eight Rubik's Social School teaching volunteers.

Observations, questionnaires, and interviews were employed in this study, which used a target situation analysis framework and a learning requirements analysis framework developed by Hutchinson and Waters (1987). A questionnaire is the primary instrument. Questionnaires are a wonderful way to conduct rapid surveys and can be used with other methods like face-to-face interviews (Pinter, 2006: 148). Students and teaching volunteers fill out questionnaires. Questionnaires for students are written in multiple choice format and written in simple language to make them easy to grasp in Indonesian. To make them more descriptive, questionnaires for teaching volunteers were created in the form of entries. Face-to-face interviews with teaching volunteers were used to follow up on the ambiguous questionnaire findings. 


\section{DISCUSSION}

Needs analysis cover target needs and learning needs. The term "target needs" refers to the requirements of the goal scenario, which entails inquiring about the target situation of the participants' attitudes during the learning process (Hutchinson and Water, 1987:59). The target demands are broken down into why English is used, how English is used, what resources will be utilized as learning materials, with whom English will be used, and when English will be used.

Because all Rubik's Social School children learn English in their different formal schools, the school offers an English learning program for its students to help them support their English learning achievement in school. Furthermore, the Rubik's Social School administrator wishes for English learning to be the foundation so that children grow comfortable with the language and are better equipped to attend English lessons at the next level of school.

Pupils of Rubik's Social School are elementary school students, hence they are considered young learners. As a result, the material taught includes simple vocabularies and chunks whose topics are very close to children, such as numbers, body parts, color, food and drink, animals, family, house, school, and other topics, in accordance with the character that they are more interested in things related to themselves and the environment around them. Because the program is only once a week with an average duration of 1-1.5 hours, English for Rubik's Social School students is only practiced in classes with a very limited period.

Learning English at the Rubik's Social School is not a compulsory subject. Because it is a social school, students' attendance is contingent on their willingness to attend. Almost all students said they enjoyed English classes because the teacher explained the content well, gave incentives for correct answers, and played games in class. The Rubik's Social School pupils' favorable attitude toward learning English is an indicator that learning English can be well received, and it serves as a foundation for teaching volunteers to increase the quality of English learning activities.

According to the results of the survey, the most pleasant English learning tactics are games (66 percent), question and answer (12 percent), stories read (10 percent), pictures (4\%), songs (4\%), and watching videos $(4 \%)$. According to the results of these responses, the majority of them believe that games are the most enjoyable learning method; however, for 
the implementation of learning English, it must be alternated with variations of other learning strategies.

The available sources include the teacher, the teacher's attitude towards learning English, the teacher's knowledge of English materials and tools (Hutchinson and Water, 1987:63). The Rubik's Social School teaching volunteers consist of 8 people, 4 people aged less than 20 years, 3 people aged 20-30 years and 1 person aged 30-40 years. Therefore, most of the Rubik's teaching volunteers are under 30 years old. Based on the questionnaire data, $25 \%$ have English education background and $75 \%$ do not have English education background.

The volunteers are students from a variety of Jakarta institutions, representing a variety of subjects, who have never attended any English teacher training or courses. Rubik's teaching volunteers have spent 87 percent of their time teaching for less than a year and 13 percent for more than a year. Teachers must be fluent in English and capable of instructing youngsters (Damayanti, 2008), hence a poor educational background can be a disadvantage. As a result, Rubik's social school directors can collaborate with colleges that specialize in education to provide English language skills training and early childhood teaching skills.
Before teaching, teaching volunteers usually prepare themselves by looking for material from sources on the internet. However, the material is unstructured depending on what you can think of and find on the internet. They usually teach speaking skills to students and most of the students are interested in communicating in English. In line with the student questionnaire which stated that most Rubik's students had a positive perception of learning English.

From the results of the questionnaire, it is known that the difficulties faced are class management, lack of preparation for teaching, lack of supporting tools, lack of mastery of materials. A non-English background makes this difficult. The syllabus and teaching materials are important to be compiled to serve as guidelines for teaching. There are several expectations from teaching volunteers, including having a definite and organized learning method, learning facilities need to be equipped to make it easier to convey material, there is a syllabus and teaching materials, adequate learning media, and many teaching reference books.

The available learning facilities include whiteboards, markers, and flashcards. The facilities are sufficient to support but the blackboard is not big 
enough so it is not visible to the students. In addition, the number of flashcards is limited so that flashcards must be reproduced to support learning activities.

Who are the students in terms of their age, gender, nationality, prior knowledge of English, interests, sociocultural background, preferred method of learning, and attitude toward English (Hutchinson and Water, 1987:63) Students of Rubik's Social School range in age from 8 to 12 years old. They live in the Bogor Regency's neighborhood. Almost all of the language they speak at home is Indonesian; only a handful speak Sundanese or Javanese, and they all speak Indonesian at school. In their different formal schools, they all take English classes. They also have a good attitude toward English, since most of the survey respondents claimed that learning English is enjoyable.

Every Sunday from 14:00 to $15: 00$, English lessons are conducted at Rubik's Social School for one hour. The Rubik's Social School classroom is extremely large and has carpeting. There are no chairs, so students can sit flat and move freely while learning.

From the analysis above, it can be seen that the target of learning English needs at the Rubik Social School is to support English lessons in formal schools. The target learners are children of primary school age who live around the Rubik's Social School. The material that needs to be taught is simple vocabularies and chunks with topics that are close to children's daily lives. The implementation of learning is carried out in the Rubik's Social School classroom with a duration of 1-1.5 hours.

For learning needs, children take English lessons because they like English. They tend to be happy because the teaching volunteers provide material clearly, hold games and give prizes if they succeed in answering questions. Learners at the Rubik's Social School use Indonesian as their daily language. Teaching volunteers have a disadvantage because they do not have an English education background, but they have a passion for teaching children. Learning media in the form of whiteboards and markers and some use flashcards. Learning is carried out in a classroom without chairs and tables so that children are free to move.

\section{CONCLUSION}

Based on the needs analysis for English at the Rubik's Social School, a curriculum and teaching materials should be created to serve as a guide for the Rubik's teaching volunteers so that learning activities, they carry out are more focused and have clear goals. There should also be training programs for volunteers who teach 
youngsters English language skills and teaching methodologies. Then, because it boosts children's passion for learning, more teaching media in the form of flashcards should be created. As long as, the pandemic situation, it also needs consideration for the innovation of teaching method.

\section{REFERENCES}

Alwasilah, A.C. (2007). CTL menjadikan kegiatan belajar mengasyikan dan bermakna. Bandung: Mizan Learning Centre.

Astika, G.(1999). The role of needs Analysis in English specific purposes. TEFLIN Journal, 10(1), 31-47

Creswell, J. W. (1994). Research design qualitative and quantitative. approaches.London: Sage Publications

Damayanti, I.L. (2008). Is the younger the better? Teaching English to young learners in Indonesian context. Educare: International Journal for Educational Studies, 1(1), 31-38

Harmer, J. (2001). The practice of English language teaching. Essex: Pearson Education Limited

Hashemi, M dan Azizinezhad. (2011). Teaching English to Children: A Unique, Challenging Experience for Teachers, Effective Teaching Ideas. Procedia-Social and Behavioral Sciences, 30 (2011) 2083-2087

Hutchinson, T. \& Waters, A. (1987) English for specific purposes: A learning centered approach. Cambridge: Cambridge University Press

Juhana. (2014). Teaching English to Young Learners: Some points to be considered. Asian Journal of Education and e-learning, 2(1), 43-46

Lestari, A.R.E. (2014). Analisis terhadap Kebutuhan Pengajaran Bahasa Inggris Berbasis Karakter. DEIKSIS, 6(3,) 153-22

Pinter, A. (2006). Teaching young language learners. Oxford: Oxford University Press. 